\title{
The Role of Electronic Word of Mouth, Health Protocol, Perceived Usefulness and Perceived Enjoyment to Intention to Book of Boutique Hotel During Covid-19 Pandemic
}

\author{
Precellina ${ }^{1, *}$ Aswin Dewanto Hadisumarto ${ }^{1, *}$
}

\author{
${ }^{1}$ Faculty of Economics and Business, Universitas Indonesia \\ *Corresponding author.Email: : precellina@ui.ac.id
}

\begin{abstract}
eWOM has become an important source of additional information for customers in determining the purchase of a product or service such as a hotel. Unfortunately, Covid-19 pandemic occurred in 2020 and changed consumer behavior regarding information needs to fulfill their sense of secure to stay at hotel. Therefore, this study aims to examine the role of electronic word of mouth of boutique hotels and information on the application of health protocols on the intention to book boutique hotels during the Covid-19 pandemic by paying attention to consumer perceived usefulness and enjoyment aspects. A total of 216 responses to a survey were collected. Structural Equation Model (SEM) was used to analyze data using PLS-SEM to test the hypotheses. The results of this study is perceived usefulness and perceived enjoyment of electronic word of mouth and health protocol influence significanly to hotel booking intention. This means that it indicates that online reviews and application of health protocols are perceived as useful and fun information to use that encourages customer boutique hotel booking intentions. During this pandemic, the results also showed that customers prioritized the fulfillment of utilitarian values, namely searching for information about the hotel as a whole as perceived usefulness of hotel online reviews as an external factor in hotel management and the application of hotel health protocols as an internal factor in hotel management before stay. The managerial implication of this research encourages boutique hotel management to to provide the best service and promote the uniqueness of boutique hotels to encourage good and detail reviews and implement health protocol in order to increase boutique hotel booking intentions.
\end{abstract}

Keywords: Covid-19, Electronic Word of Mouth, Health Protocol, Intention to Book, Perceived Usefulness, Perceived Enjoyment.

\section{INTRODUCTION}

Technological advances have encouraged the creation of online media and businesses [1] such as online travel agents that provide accommodation tickets and hotel. This media also provides reviews and assessments by visitors as electronic word of mouth, which is a positive or negative statement made by previous customers regarding a product that is available to many people and via internet [2].

Currently, there is a new hotel classification, namely themed hotels with boutique hotels as an example [3]. Boutique hotels are called Instagramable hotels which are perfect if hotel visitors want to do a staycation as one of the new trends in vacation. In Indonesia, the most popular boutique hotels are usually found in big cities which are favourite tourist destinations [4]. The large selection of hotels in Indonesia makes eWOM one of the important considerations regarding additional information that is deemed necessary considering that the nature of a service cannot be perceived first so that consumers search for this information before making a decision to reduce uncertainty and complexity [5].

Unfortunately, in 2020, the world was shocked by the Covid-19 virus outbreak which became a global pandemic. The impact of the Covid-19 pandemic has 
reduced the interest of Indonesian consumers to travel based on a survey released by OYO through McKinsey

The survey showed the interest in staying at a hotel has decreased by $84 \%$. Hotels are expected to follow the guidelines that have been established in carrying out their operational activities, this can also be said to be a health risk mitigation. Most of tourists would hesitate to travel because they thought about their health, for this reason hotel and tourism management felt it was important implement strategies to reduce these risks [7]. Implementing this health protocol is mandatory to maintain safety and comfort for visitors or hotel staff.

Reading reviews can also help customers get value through these reviews and it can also be said that value is perceived value [8]. If tourists find reviews about hotels that are considered useful, they will see the utilitarian value of these reviews, which is also represented as perceived usefulness of reviews that can help fulfill the task, conversely if they find that the review is a fun review what is seen as the hedonic value of the reviews which can be represented by perceived enjoyment as a pleasant information to be read and used [9], [10]. In some previous studies, perceived usefulness and perceived enjoyment of the online review proved to have a significant influence on the online purchase and intention to book hotel.

Research on the role of eWOM on the intention to book hotels may have been found several times but using boutique hotels the object of research, especially in Indonesia has not been done much, even though boutique hotels with a smaller staying capacity than other hotels will be high in demand because they give the impression of being safe and comfortable after the Covid-19 pandemic because customers can avoid large crowds [11].

Given that the role of eWOM is better to be observed to provide insight to hotel management. Other issues concerning the application of health protocols in a boutique hotel as one of the measures implemented to mitigate the health risks have not found research that showed a lot of influence on the intention of ordering a boutique hotel. So if it is concluded that this study aims to see the role of online reviews of boutique hotels as external factors and health protocols as internal hotel factors that are applied to boutique hotel booking intentions by paying attention to the perceived usefulness and perceived enjoyment of consumers on online reviews and information on the application of health protocols.

\section{LITERATURE REVIEW}

This study uses several theories regarding eWOM, health protocols as health risk mitigation, perceived usefulness, perceived enjoyment, intention to book and boutique hotels.

\subsection{Electronic Word of Mouth}

With advances in information technology, the form of word of mouth is replaced by a more modern form, namely electronic word of mouth which has a more relevant effect on technological developments and can reach a wider audience with geographical and time constraints [12]. Besides known as negative and positive reviews, eWOM can also be referred to as online customer review which has a definition of numerical ratings or descriptive comments provided by current and past customers that are used to express satisfaction or dissatisfaction, often conveyed by opinions or recommendations about experiences with products or services [13]. In addition to positive and negative reviews, the quality of reviews has several times been a research dimension that has an influence on buyers behavioral intentions.

\subsubsection{Positive Electronic Word of Mouth}

Positive reviews submitted by customers are a form of expression of their satisfaction with the experience of using the product or service. Customers will be more willing to leave positive reviews on behalf of the seller when they are satisfied with the quality of service they get [14]. Positive online consumer reviews are more proven to be effective in increasing consumer intention to place orders than negative online reviews [15].

\subsubsection{EWOM Quality}

Quality of reviews is characteristic of review and a persuasive power of a review that is on the review itself

[16]. eWOM quality usually consists of several dimensions. The dimensions of eWOM quality that are commonly used in similar research are comprehensiveness regarding the completeness of the review, relevance regarding the suitability of the review, accuracy regarding the precision of the review and the timeliness is the most recent of review [17], [18]. In the online context, according to some researchers, the 
quality of information received by customers can influence purchasing decisions.

\subsection{Health Protocol}

The outbreak of the Covid-19 pandemic had a huge impact on almost all industries, including the tourism and hospitality industry. There are several actions that can be taken to improve the prevention of this outbreak in the future. Some of the actions that can be taken are mobility restriction, physical distancing, hygiene measures, socio-economic restrictions, communication and international support mechanisms [19]. Most of tourists will hesitate to travel because they concern with their health, it is important for hotel management to implement strategies to reduce these risks [7] and make them feel safer to stay.

\subsection{Perceived Value of Online Review}

It is not uncommon for travelers to read online reviews to get the additional information they need or to enjoy reading reviews that have been posted by other travelers [8]. Reading these reviews customers can also get value through these reviews. If travelers find a review of a hotel that is considered helpful, they will see the utilitarian value of the review, conversely if they find that the review is a pleasant review, what they see is the hedonic value of the review [8]. Utilitarian value represented by perceived usefulness and hedonic value represented by perceived enjoyment [10]. Perceived usefulness and perceived enjoyment as derived attributes of a review can be something useful and fun to read and have an influence on online purchase intentions [9].

\subsubsection{Perceived Usefulness}

Recommendations have an important role in the customer decision-making process when they want to purchase new goods or services that have a high price [20]. Perceived usefulness of recommendations to dominate blogger blog user attitude towards online shopping [20]. This research adapts perceived usefulness of information or online reviews [9] and the application of health protocols from boutique hotels to online travel agents that are perceived by customers because perceived usefulness of online customer review had a significant influence on online purchase as well as being one of the important elements that directly affect consumer intention to shop online.

\subsubsection{Perceived Enjoyment}

Perceived enjoyment refers to the extent to which customers feel that online reviews are fun and entertaining [9]. The perceived enjoyment resulting from online reviews has a significant effect on customer intentions to shop online. In the same result, it is seen that the more online reviews can be enjoyed, the stronger the customer will do online shopping [9].

\subsection{Intention To Book}

Behavioral intention is an important factor of loyalty which refers to the possibility of engaging in a real behavior or action [21]. If consumers feel that they have got the information they need, in general they will proceed to the next step, which is to make an actual purchase. In the tourism sector, especially the hotel industry, this is commonly referred to as hotel booking intention through hotel websites [22].

\subsection{Boutique Hotel}

Boutique hotels are small hotels that are unique in their decoration and sometimes even historic and each room has individually decorated and has a price range from mid-range to luxury hotels and there are boutique hotels that are independent and affiliated with certain brands [3]. Boutique hotel designs attract visitors who are looking for a different property and can fulfill what they are looking for.

\section{RESEARCH METHODOLOGY}

Research methodology consists of research framework, research hypotheses and data analysis methods.

\subsection{Research Framework}

Figure 1 shows the research framework of this research.

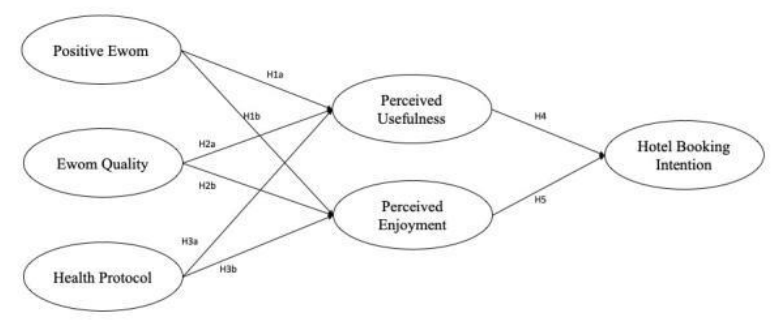

Figure 1 Research framework. 


\subsection{Research Hypothesis}

\subsubsection{EWOM to Perceived Usefulness and Perceived Enjoyment}

Before finally making a choice, the visitors usually gather some additional information to convince their choice of hotel. Research by Elwalda et al. [9] who looked at perceived usefulness and perceived enjoyment as seen from online reviews of online purchase intentions and found significant results. research by Chong et al. [23] who found that the perceived usefulness of good quality of online review can fully mediate the perceived usefulness of information in determining travel decisions based on online reviews, then this research hyphothesis will refer to:

H1a: positive eWOM has significant effect on the perceived usefulness.

H1b: positive eWOM has significant effects the perceived enjoyment.

H2a: eWOM quality has significant effects the perceived usefulness.

H2b: eWOM quality has significant effects the perceived enjoyment.

\subsubsection{Health Protocol to Perceived Usefulness and Perceived Enjoyment}

Implementation of health protocols in the hotel as risk mitigation to prevent the transmission of Covid-19 also considered as an important thing to do and make consumer feel safer to stay. Implementation of health protocols using hygiene products for hands and disinfectants have been shown to be influential in preventing the spread of viruses in hotel guest's rooms and in conference rooms [24]. It is assumed that information regarding the application of health protocols can be both useful and pleasant information. then this research hypothesis will refer to:

H3a: the application of health protocols has significant effects the perceived usefulness.

H3b: the application of health protocols has significant effects the perceived enjoyment.

\subsubsection{Perceived Usefulness to Intention to Book}

Perceived usefulness of blogger recommendations and online review [20], [9] found results that had a significant effect on online purchase intentions. The more useful the online review, it increases the intention to do online purchase. Then this research hypothesis will refer to:

H4: perceived usefulness as seen from online reviews and information on the application of hotel health protocols displayed on online travel agents has an effect on hotel booking intentions.

\subsection{Data Analysis Method}

This research is a conclusive research using primary data by distributing questionnaires using Google Form. The time dimension of this research is cross-sectional research. The scale used in the questionnaire is a Likert scale (1-5) for measuring each variable indicator. This research uses nonprobability sampling with a sample of people who know and have an online travel agent application, aged 18 and above, have read the reviews as additional information, know boutique hotels and have the intention to stay in the next year where this pandemic is still predicted to continue. This study uses SPSS 25.0 for pre-test and uses PLSSEM to perform the main test of the study. This research also use bootstrapping technique used in order to get more precise and significant result.

\section{RESULTS}

Total respondents of this research is 216 respondents. First test is pre-test and the result of reliability test and validity test of each variable is above 0.5 and 0.6. The next test is main test that divided into outer model and inner model test. There were no problems found from the result that can be said that all variables are also valid and reliable. Based on the collected data from respondents, this research found that 6 hypotheses, H1a, H2a, H2b, H3a, H4 and H5, were accepted with the results having a significant effect, while the other 2 hypotheses, H1b and H3b, were not found to be significant from hypothesis testing. Reviews and health protocols were found to be useful information, especially during the Covid-19 pandemic in accordance with changing interests and meeting customer needs for information that could increase hotel booking intentions.

Table 1. Result of The Research Hypothesis

\begin{tabular}{|c|c|c|c|}
\hline Hypothesis & T Statistics & P Values & \\
\hline Positive EWOM > & 2.693 & 0.006 & Supported
\end{tabular}




\begin{tabular}{c|c|c|c|}
\hline Hypothesis & T Statistics & P Values & \\
Perceived Usefulness & & & \\
\hline $\begin{array}{c}\text { Positive EWOM > } \\
\text { Perceived Enjoyment }\end{array}$ & 0.629 & 0.534 & Rejected \\
\hline $\begin{array}{c}\text { EWOM Quality > } \\
\text { Perceived Usefulness }\end{array}$ & 10.572 & 0.000 & Supported \\
\hline $\begin{array}{c}\text { EWOM Quality > } \\
\text { Perceived Enjoyment }\end{array}$ & 10.123 & 0.000 & Supported \\
\hline $\begin{array}{c}\text { Health Protocol > } \\
\text { Perceived Usefulness }\end{array}$ & 4.666 & 0.000 & Supported \\
\hline $\begin{array}{c}\text { Perceived Enjoyment } \\
\text { Intentiontion to Book }\end{array}$ & 5.524 & 0.000 & Supported \\
\hline $\begin{array}{c}\text { Health Protocol > } \\
\text { Perceived Enjoyment }\end{array}$ & 0.125 & 0.901 & Rejected \\
\hline & 4.451 & 0.000 & Supported \\
\hline & & & \\
\hline
\end{tabular}

\section{DISCUSSION}

H1a is accepted, positive eWOM has a significant effect on perceived usefulness, which means that online reviews, especially positive reviews displayed on online travel agents, are considered to be additional useful information when building intentions in ordering boutique hotels. Online reviews are online reviews that are dominated by positive and negative online reviews which are proven to be useful and affect customer attitudes and intentions compared to neutral online reviews [25].

$\mathrm{H} 1 \mathrm{~b}$ is rejected, this positive eWOM tends to have no effect on perceived enjoyment or is not felt to be additional information in the form of online reviews, especially in this study positive online reviews, which cause pleasure while use or read that review. The results of this study do not support similar previous studies who found the influence of online review on perceived enjoyment that can increase intention to online purchase [9].

$\mathrm{H} 2 \mathrm{a}$ is accepted, online reviews of boutique hotels including reviews that cover the unique values of boutique hotels and in-depth reviews that also include information on implementing health protocols are considered to be reviews of good quality and useful information for consumers. The completeness of review can help potential visitors in deciding their choice. The research results are in line with the results of previous studies that found eWOM quality has significant influence to perceived enjoyment [18], [23].

$\mathrm{H} 2 \mathrm{~b}$ is accepted, potential visitors who read online reviews of boutique hotels that explain about uniqueness and interesting things of the hotel are considered to be fun and enjoyable information because they can find out what other visitors are reviewing about the uniqueness offered at the boutique hotel both in terms of decoration, design or anything related to its uniqueness. The research results are in line with the results of previous studies that found eWOM quality has significant influence to perceived enjoyment [9].

$\mathrm{H} 3 \mathrm{a}$ is accepted, implementation of health protocols as a risk mitigation measure for hotel health that is informed and displayed on online travel agents is felt and trusted by potential boutique hotel visitors as useful information, especially during the current Covid-19 pandemic due to changes in consumer behavior who are currently concerned about their safety staying at hotel. This information is assumed to be similar to information that can be found online at online travel agents so that it is in line with previous research [9]. Meanwhile, H3b is rejected because health protocol not become something pleasant but something useful as additional information.

$\mathrm{H} 4$ is accepted, the more positive an online boutique hotel review is, the more complete the boutique hotel review is, covering the unique value offered by a boutique hotel, the relevance of the experience felt by previous visitors will be useful information to help them determine their choice and intention to book the boutique hotel. The more useful the information and the more it feels in accordance with what is needed by potential boutique hotel visitors, the intention to book a boutique hotel will also increase and in line with [9]. Similar research in different contexts also found similar results, hotel virtual presentations tends to be a useful for evaluating hotels, it will increase the intention to 
book hotels and give an indication that the utilitarian value of using hotel virtual presentations is an important factor [10].

H5 is accepted, the biggest influence that affects perceived enjoyment is good information quality which contains a complete and detailed review that explains the uniqueness of the boutique hotel as the results of the previous hypothesis and not only in the form of reviews that state experiences and positive values but reviews that are clear, complete and include all values are uniqueness and in line with [9].

\begin{tabular}{|c|c|}
\hline Variable & $\mathrm{R}^{2}$ \\
\hline Positive EWOM & \\
\hline EWOM Quality & 1 \\
\hline Health Protocol & \\
\hline Perceived Usefulness & 0.671 \\
\hline Perceived Enjoyment & 0.435 \\
\hline Intention to Book & 0.439 \\
\hline
\end{tabular}

Figure 1. Coefficient Determination $\left(\mathrm{R}^{2}\right)$

Based on image 1 which contains the results of research coefficient determination, the variable of perceived enjoyment and intention to book have small contribution, namely $43.5 \%$ and $43.9 \%$ of exogenous variables because these variables could be influenced by other factors outside of this research variable. Meanwhile, perceived usefulness and eWOM quality have been largely explained by exogenous variables. This can be recommendation for future research that uses similar topics such as hotel virtual application, starcategory, price, brand image and the other that can affect perceived enjoyment and hotel booking intention outside eWOM.

\section{CONCLUSION AND IMPLICATION}

\subsection{Conclusion}

Based on conducted test, this research found that 6 hypotheses were accepted with the results having a significant effect, while the other 2 hypotheses were not found to be significant. The perceived usefulness of online reviews and information on the application of health protocols can provide an overview of boutique hotels, especially as additional information needed by visitors during the Covid-19 pandemic. They need complete information and reviews including the application of health protocols that are supported by changes in consumer interests and behavior in deciding to stay at this time. The complete review about uniqueness of boutique hotel found to be a fun information to read so good quality of review has affected perceived enjoyment and increase intention to book the hotel. If it can be ranked, based on the respondent result, they feel eWOM quality has the most important role of a review. They attach importance to getting and using good quality review that include completeness and accuracy of a review. Furthermore, considering current condition is still in Covid-19 pandemic the implementation of health protocol is also the focus of hotel visitors, followed by positive reviews about the hotel based on visitors' importance ranking about hotel in this research.

\subsection{Implication}

Hotel management needs to improve both in terms of services provided and optimal hotel facilities in order to encourage previous boutique hotel visitors to write positive reviews about the boutique hotel itself on available platforms such as online travel agents as a platform used to search for boutique hotels and read reviews about the boutique hotel. Boutique hotel management can emphasize the unique value of boutique hotels to be promoted, such as examples of the design used, room decoration and other unique aspects that differentiate it from other hotels so that reviews written by boutique hotel visitors can be reviewed what is unique about the hotel and can be useful information for future visitors who want a different experience and atmosphere from the other hotel categories. Hotel management can also consider to collaborates with wellknown and credible travel influencers to share detailed boutique hotel reviews on social media and other platforms. Sharing information on the application of health protocols can also be an idea to promote boutique hotels so that visitors are interested in staying overnight because they do not override the applicable health protocol regulations which are important for visitors. It is also felt this will provide more value for boutique hotels if hotel management is always updated on information that is important to share, especially for prospective hotel visitors who will stay during the Covid-19 pandemic. Online travel agent management is thought to be able to provide guidelines for writing online reviews from visitors about boutique hotels so that they can have guidelines for writing detailed review.

\section{AUTHORS' CONTRIBUTIONS}

Author conducted this research supervised by guidance from A.D.H to get the final results. All feedback from the authors help to complete this research in order to be 
beneficial to academics and practitioners with related topics.

\section{ACKNOWLEDGMENTS}

This research would not have been successful without the help and guidance of Aswin D. Hadisumarto, MIA as my supervisor. His knowledge and time given to supervise this research that makes things run on track. As well as for the respondents who participated to fill out the questionnaire so this study got expected results that can be useful.

\section{REFERENCES}

[1] Databoks. (2019). Berapa Pengguna Media Sosial Indonesia?.

https://databoks.katadata.co.id/datapublish/2019/02 /08/berapa-pengguna-media- sosial-indonesia

[2] Hennig-Thurau, T., Gwinner, K. P., Walsh, G., \& Gremler, D. D. (2004). Electronic word- of-mouth via consumer-opinion platforms: What motivates consumers to articulate themselves on the Internet? Journal of Interactive Marketing, 18, 38e52.

[3] Putri, Arum Sutrisni. (2020). Klasifikasi Hotel.

https://www.kompas.com/skola/read/2020/01/10/162 220869/klasifikasi- hotel?page=all

[4] Yohannaes, Markus. (2020). 15 Hotel Butik di Indonesia Terpopuler dengan Desain Stylish!. https:// www.traveloka.com/idid/explore/destinatio n/best-boutique-hotels-inindonesia-acc/28520

[5] Yen, C. L. A., \& Tang, C. H. H. (2019). The effects of hotel attribute performance on electronic word-of-mouth (eWOM) behaviors. International Journal of Hospitality Management, 76, 9-18.

[6] Khoiri, Ahmad Masaul. (2020). Tren dan Perubahan Industri Perhotelan Indonesia di Era

New Normal. $\quad$ https://travel.detik.com/travelnews/d-5046130/tren -dan-perubahan- industriperhotelan-indonesia-di-era-new-normal

[7] Shin, H., \& Kang, J. (2020). Reducing perceived health risk to attract hotel customers in the COVID-19 pandemic era: Focused on technology innovation for social distancing and cleanliness. International Journal of Hospitality Management, 91, 102664.

[8] Ham, J., Lee, K., Kim, T., \& Koo, C. (2019). Subjective perception patterns of online reviews: A comparison of utilitarian and hedonic values. Information Processing \& Management, 56(4), 1439-1456.

[9] Elwalda, A., Lü, K., \& Ali, M. (2016). Perceived derived attributes of online customer reviews. Computers in Human Behavior, 56, 306-319.

[10] Israel, K., Zerres, C., \& Tscheulin, D. K. (2019). Presenting hotels in virtual reality: does it influence the booking intention?. Journal of Hospitality and Tourism Technology.

[11] Wartaekonomi.co.id. (2020) "Bangkit Dari Kubur, OYO Siapkan Strategi New Normal”. Republika Online, Republika Online. http:// republika.co.id/berita/qbmf319017000/bangkitdari-kubur-oyo-siapkan-strategi-new- normal

[12] Yen, C. L. A., \& Tang, C. H. H. (2019). The effects of hotel attribute performance on electronic word-of-mouth (eWOM) behaviors. International Journal of Hospitality Management, 76, 9-18.

[13] Fang, B., Ye, Q., Kucukusta, D., \& Law, R. (2016). Analysis of the perceived value of online tourism reviews: Influence of readability and reviewer characteristics. Tourism Management, 52, 498-506

[14] Athanassopoulos, A., Gounaris, S., \& Stathakopoulos, V. (2001). Behavioural responses to customer satisfaction: An empirical study. European Journal of Marketing, 35(5), 687- 707.

[15] Tsao, W. C., Hsieh, M. T., Shih, L. W., \& Lin, T. M. (2015). Compliance with eWOM: The influence of hotel reviews on booking intention from the perspective of consumer conformity. International Journal of Hospitality Management, $46,99-111$

[16] Bhattacherjee, A., \& Sanford, C. (2006). Influence processes for information technology acceptance: An elaboration likelihood model. MIS quarterly, 805-825.

[17] Cheung, C. M., Lee, M. K., \& Rabjohn, N. (2008). The impact of electronic word-of-mouth: The adoption of online opinions in online customer communities. Internet Research: Electronic Networking Applications and Policy, 18(3), 229. 247.

[18] Matute, J., Polo-Redondo, Y., \& Utrillas, A. (2016). The influence of EWOM characteristics on online repurchase intention. Online Information Review. 
[19] de Bruin, Y. B., Lequarre, A. S., McCourt, J., Clevestig, P., Pigazzani, F., Jeddi, M. Z., ... \& Goulart, M. (2020). Initial impacts of global risk mitigation measures taken during the combatting of the COVID-19 pandemic. Safety Science, 104773.

[20] Hsu, C. L., Lin, J. C. C., \& Chiang, H. S. (2013). The effects of blogger recommendations on customers' online shopping intentions. Internet Research.

[21] Han, H., \& Hyun, S. S. (2017). Impact of hotelrestaurant image and quality of physicalenvironment, service, and food on satisfaction and intention. International Journal of Hospitality Management, 63, 82-92.

[22] Lien, C. H., Wen, M. J., Huang, L. C., \& Wu, K. L. (2015). Online hotel booking: The effects of brand image, price, trust and value on purchase intentions. Asia Pacific Management Review, 20(4), 210-218.

[23] Chong, A. Y. L., Khong, K. W., Ma, T., McCabe, S., \& Wang, Y. (2018). Analyzing key influences of tourists' acceptance of online reviews in travel decisions. Internet Research.

[24] Sifuentes, L. Y., Koenig, D. W., Phillips, R. L., Reynolds, K. A., \& Gerba, C. P. (2014). Use of hygiene protocols to control the spread of viruses in a hotel. Food and environmental virology, 6(3), 175-181

[25] Purnawirawan, N., De Pelsmacker, P., \& Dens, N. Balance and sequence in online reviews: How perceived usefulness affects attitudes and intentions. Journal of interactive marketing, 26(4), 244-255. 